\title{
PENETAPAN MASA JABATAN JAKSA AGUNG RI BERDASARKAN PUTUSAN MK NO. 49/PUU-VIII/2010 TENTANG PENGUJIAN UNDANG-UNDANG NOMOR 16 TAHUN 2004 TENTANG KEJAKSAAN RI DALAM SISTEM PENETAPAN JABATAN PEJABAT NEGARA MENURUT UUD NRI 1945
}

\author{
Titik Triwulan Tutik ${ }^{1}$
}

\begin{abstract}
Abtract
Attorney position is standing on two sides, the judiciary and the executive, which then lead to a contradiction in the settings (dual obligation). Historically Attorney who initially non-departmental agency status under the justice department into a stand-alone agency, department separated from the Department of Justice and the Supreme Court, until today. Legislation on RI Attorney nothing definitive and limitative set how long the Attorney General took office. However, after the 1971 election of President Suharto began a constitutional convention, the Attorney General who is raised in the initial cabinet and ended his tenure with the expiration of the term of the cabinet. In other words, the Attorney General's term of office is 5 (five) years. Constitutional Court in Constitutional Court Decision No. Amar. Testing 49/PUU-VIII/2010 of Article 22 Paragraph (1) of Law No. Clause d. 16 of 2004 on the Attorney RI despite the ruling of the constitutional conditionally (conditionally constitutional) clearly refers to the fact the Court over the constitutional convention. Meaning tenure as Acting Attorney General of the State-level Ministry of countries that are members of the cabinet as an assistant to the President is still 5 (five) years, regardless prosecution later if the new bill is being deliberated by the Shaping the Law, the Parliament and the President, at this time otherwise. Because it is a public official tenure as stipulated in the legislation is fully implemented the policy of the legislation by the House with the President. In the constitutional practice of the Republic of Indonesia there are strict rules regarding tenure systems of public officials, such as President of the set term of office for 5 (five) years and can only be reelected for a period thereafter, the term of office of the Judicial Commission for a period of 5 (five) years and thereafter be elected for one (1) term, the Constitutional Court during the tenure of five (5) years and may be re-elected only for 1 (one) time the next term or the term of office came to an end due to retirement 67 years and the term of office of Chief Justice determined until the retirement age of 70 years.
\end{abstract}

Keywords: tenure, term of office of the attorney general, official tenure system state

${ }^{1}$ Titik Triwulan Tutik adalah Dosen Fakultas Syari'ah IAIN Sunan Ampel Surabaya alumni Program Doktor Ilmu Hukum Program Pascasarjana Universitas Airlangga. Alamat kontak: tt_titik@yahoo.com. 


\begin{abstract}
Abstrak
Kedudukan Kejaksaan memang berdiri di dua sisi, yudikati dan eksekutif, sehingga kemudian menimbulkan kontradiksi dalam pengaturannya (dual obligation). Secara historis Kejaksaan yang awalnya berstatus lembaga nondepartemen di bawah departemen kehakiman menjadi lembaga yang berdiri sendiri, departemen tersendiri yang terpisah dari departemen kehakiman dan mahkamah agung, hingga saat ini. Perundang-undangan tentang Kejaksaan RI tidak ada yang mengatur secara definitif maupun limitatif berapa lama seorang Jaksa Agung menduduki jabatannya. Namun setelah pemilu 1971 Presiden Soeharto memulai sebuah konvensi ketatanegaraan, yakni Jaksa Agung yang selalu diangkat di awal kabinet dan berakhir masa jabatannya dengan berakhirnya masa bakti kabinet itu. Dengan kata lain masa jabatan Jaksa Agung adalah 5 (lima) tahun. MK dalam Amar Putusan MK No. 49/PUU-VIII/2010 tentang Pengujian Pasal 22 Ayat (1) Huruf d UU No. 16 Tahun 2004 tentang Kejaksaan RI meskipun dengan amar putusan konstitusional bersyarat (conditionally constitutional) jelas $M K$ lebih mengacu pada fakta konvensi ketetanegaraan ini. Artinya masa jabatan Jaksa Agung sebagai Pejabat Negara setingkat Menteri negara yang menjadi anggota kabinet sebagai pembantu Presiden adalah tetap 5 (lima) tahun, terlepas nanti jika RUU kejaksaan yang baru yang sedang digodok oleh Pembentuk UU, DPR bersama Presiden, saat ini menentukan lain. Karena memang penetapan masa jabatan pejabat publik yang tertuang dalam undangundang adalah sepenuhnya menjadi kebijakan legislasi yang dijalankan oleh DPR bersama Presiden. Dalam praktek ketatanegaraan Negara Republik Indonesia terdapat aturan-aturan yang tegas mengenai sistem penetapan masa jabatan pejabat publik, seperti Presiden ditetapkan masa jabatannya selama 5 (lima) tahun dan hanya dapat dipilih kembali untuk satu periode setelahnya, masa jabatan anggota Komisi Yudisial selama masa 5 (lima) tahun dan sesudahnya dapat dipilih kembali untuk 1 (satu) kali masa jabatan, masa jabatan Hakim Konstitusi selama 5 (lima) tahun dan dapat dipilih kembali hanya untuk 1 (satu) kali masa jabatan berikutnya atau masa jabatan tersebut berakhir karena memasuki usia pensiun 67 tahun dan masa jabatan Hakim Agung ditentukan sampai usia pensiun 70 tahun.
\end{abstract}

Kata kunci: penetapan masa jabatan, masa jabatan jaksa agung, sistem penetapan masa jabatan pejabat negara

\title{
I. Pendahuluan
}

UUD 1945 setelah perubahan (baca: UUDNRI 1945) menyatakan secara tegas, bahwa "Negara Republik Indonesia adalah Negara Hukum". ${ }^{2}$ Kaidah ini mengandung makna bahwa hukum di Negara ini ditempatkan pada posisi yang

${ }^{2}$ Lihat Pasal 1 ayat (3) UUDNRI 1945. 
strategis di dalam konstelasi ketatanegaraan (supremasi hukum). Agar hukum sebagai suatu sistem dapat berjalan dengan baik dan benar di dalam kehidupan berbangsa, bernegara dan bermasyarakat, diperlukan instrumen penggeraknya dan salah satunya adalah Kejaksaan Republik Indonesia.

Mewujudkan suatu Negara hukum, tidak saja diperlukan norma-norma hukum atau peraturan perundang-undangan sebagai subtansi hukum, tetapi juga diperlukan lembaga atau badan penggeraknya sebagai struktur hukum dengan didukung oleh perilaku hukum seluruh komponen masyarakat sebagai budaya hukum. Ketiga elemen ini, baik subtansi hukum, struktur hukum maupun budaya hukum oleh L.M. Friedman, dikatakan sebagai susunan sistem hukum. ${ }^{3}$

Kejaksaan Republik Indonesia sebagai salah satu institusi penegak hukum merupakan komponen dari salah satu elemen sistem hukum secara universal diberikan kewenangan melaksanakan kekuasaan Negara di bidang peuntutan dan tugas-tugas lain yang ditetapkan oleh undang-undang. Dalam hal ini dapat dikatakan, bahwa Kejaksaan Republik Indonesia memiliki posisi sentral dan peranan yang strategis di dalam suatu Negara hukum. Posisi sentral dan peranan yang strategis ini, karena berada di poros dan menjadi filter antara proses penyidikan dan proses pemeriksaan di persidangan, di samping sebagai pelaksana penetapan dan keputusan pengadilan.

Keberadaan Kejaksaan diatur secara khusus dalam Undang-Undang Nomor 16 Tahun 2004 tentang Kejaksaan Republik Indonesia (baca: UUK 2004) sebagai subordinated dari UUDNRI 1945. Dalam UUK 2004 ini dijelaskan Kejaksaan adalah lembaga pemerintah yang melaksanakan kekuasaan negara di bidang penuntutan serta kewenangan lain berdasarkan undang-undang. ${ }^{4}$ Sementara Jaksa Agung adalah pimpinan dan penanggungjawab tertinggi Kejaksaan yang memimpin, mengendalikan pelaksanaan tugas, dan wewenang Kejaksaan ${ }^{5}$. Status Jaksa Agung adalah pejabat negara yang diangkat dan diberhentikan oleh presiden ${ }^{6}$ serta

3 H.M.A. Rachman, "Kemandirian Kejaksaan RI dalam Melaksanakan Fungsi Penegakkan Hukum", Makalah yang Disampaikan pada Ceramah Jaksa Agung RI pada Acara Seminar Sehari dalam Rangka Peringatan 50 Tahun Pendidikan Hukum Universitas Airlangga, Sabtu 9 Oktober 2004, hal. 1.

${ }^{4}$ Pasal 2 Ayat (1) UUK 2004. Keberadaan Kejaksaan RI selanjutnya dipertegas lagi dalam Penjelasan Umum UUK 2004 yang merumuskan, "Kejaksaan sebagai lembaga pemerintahan yang melaksnakan kekuasaan negara di bidang penuntutan ditegaskan kekuasaan negara tersebut dilaksanakan secara merdeka. Oleh karena itu, kejaksaan dalam melaksanakan fungsi, tugas, dan wewenangnya terlepas dari pengaruh kekuasaan pemerintah dan kekuasaan lainnya. Selanjutnya ditentukan Jaksa Agung bertanggungjawab atas penuntutan yang dilaksakan secara independen demi keadilan berdasarkan hukum dan hati nurani.. Dengan demikian Jaksa Agung selaku pimpinan kejaksaan dapat sepenuhnya merumuskan dan mengendalikan arah dan kebijakan penanganan perkara untuk keberhasilan penuntutan".

\footnotetext{
${ }^{5}$ Pasal 18 Ayat (1) UUK 2004.

${ }^{6}$ Pasal 19 Ayat (1) dan Ayat (2) UUK 2004.
} 
bertanggungjawab kepada presiden. Dari sini jelas bahwa Jaksa Agung berada dibawah kekuasaan eksekutif, di bawah presiden. Oleh karena itu jabatan Jaksa Agung dikatakan setingkat menteri negara. Dengan demikian yang berhak mengangkat dan memberhentikanya adalah presiden, melalui Keputusan Presiden (Keppres).

Membicarakan jabatan tentu juga berkaitan dengan masa jabatan. Dalam UUK 2004 tidak dijelaskan secara definitif berapa lama masa jabatan Jaksa Agung, periode jabatan atau lama masa baktinya. Namun berdasarkan konvensi ketatanegaraan sejak Indonesia merdeka masa jabatan Jaksa Agung disamakan dengan menteri-menteri sebagai anggota kabinet yang membantu presiden. Oleh karena itu masa jabatannya mengikuti masa bakti presiden yaitu 5 (lima) tahun. Walaupun demikian, presiden dengan hak prerogatifnya dapat sewaktuwaktu memberhentikannya dari jabatan dan mengangkat pejabat baru. Pengangkatan pejabat baru bisa karena satu dan lain sebab, misalnya perombakan (reshuffle) kabinet.

Pada masa Presiden Susilo Bambang Yudhoyono dan Wakil Presiden Jusuf Kalla (periode 2004-2009) terjadi 2 kali reshuffle kabinet. Pada reshuffle kabinet yang kali kedua, Hendarman Supandji dilantik menggantikan Jaksa Agung Abdurrahman Saleh. Hendarman terus menjabat hingga berakhirnya masa bakti presiden, wakil presiden dan Kabinet Indonesia Bersatu I (baca: KIB I). Kemudian pasca pemilu presiden 2009 yang dimenangkan oleh pasangan Susilo Bambang Yudhoyono-Boediono, pada tanggal 20 Oktober 2009 Kabinet Indonesia Bersatu I dibubarkan dan pada tanggal yang sama diumumkan pembentukan Kabinet Indonesia Bersatu II (baca: KIB II) sekaligus pelantikannya untuk periode 2009-2014. Namun ada yang tidak biasa pada saat itu. Jaksa Agung Hendarman Supandji menjadi satu-satunya pejabat yang tidak disebut namanya dalam Keppres pemberhentian menteri-menteri KIB I dan tidak pula pada Keppres pengangkatan menteri-menteri KIB II. Hendarman justru langsung menjabat dan meneruskan tugasnya sebagai Jaksa Agung untuk periode 2009-2014. Dan hal inilah yang memicu diajukannya judicil review oleh Yusril Ihzamahendra terhadap Pasal 22 Ayat (1) Huruf d UU No. 16 Tahun 2004 tentang Kejaksaan RI kepada Mahkamah Konstitusi. Selengkapnya pasal 22 ayat (1) menegaskan sebagai berikut:

\section{Jaksa Agung diberhentikan dengan hormat dari jabatnnya karena:}

a. meninggal dunia;

b. permintaan sendiri;

c. sakit jasmani atau rohani terus-menerus;

d. berakhir masa jabatannya;

e. tidak lagi memenuhi salah satu syarat sebagaimana dimaksud dalam Pasal 21.

Menurut Yusril klausul huruf $d$ tersebut tidak jelas sehingga multitafsir (polyinterpretabel) karena tidak menjelaskan dengan pasti kapan seorang Jaksa Agung dianggap berakhir masa jabatannya. Klausul itu dapat saja ditafsirkan 
seumur hidup ${ }^{7}$ selama tidak diberhentikan dan sebagainya. Hal ini dapat menimbulkan ketidakpastian hukum (rechsonzekerheid) sehingga Yusril mengajukan permohon agar MK sebagai the guardian of constitution dan the final interpreter of the constitution agar memberikan tafsir yang pasti. ${ }^{8}$

Pengajuan judicial review itu telah diputus oleh MK dengan Putusan MK No. 49/PUU-VIII/2010 tentang Pengujian Undang-Undang Nomor 16 Tahun 2004 tentang Kejaksaan RI [Pasal 22 Ayat (1) Huruf d] yang inti amar putusannya memberikan tafsir terhadap klausul huruf $\mathrm{d}$ sebagai berikut:

Pasal 22 Ayat (1) Huruf d UU No. 16 Tahun 2004 Tentang
Kejaksaan RI sesuai dengan UUD 1945 secara bersyarat
(conditionally constitutional), yaitu konstitusional sepanjang
dimaknai "masa jabatan Jaksa Agung itu berakhir dengan
berakhirnya masa jabatan Presiden Republik Indonesia dalam satu
periode bersama-sama masa jabatan anggota kabinet atau
diberhentikan dalam masa jabatannya oleh Presiden dalam
periode yang bersangkutan". Penafsiran selain yang sudah
ditetapkan mengakibatkan klausul huruf dersebut tidak memiliki
kekuatan hukum mengikat.

Berdasarkan ketentuan Putusan MK No. 49/PUU-VIII/2010 tentang Pengujian Undang-Undang Nomor 16 Tahun 2004 tentang Kejaksaan RI melahirkan beberapa isu hukum: Pertama, bagaimanakah ketentuan-ketentuan hukum yang pernah berlaku mengatur mengenai penetapan masa jabatan jaksa agung. Kedua, bagaimanakah penetapan masa jabatan jaksa agung dalam sistem penetapan jabatan pejabat negara.

Berdasarkan isu hukum tersebut kerangka pembahasan dalam artikel ini meliputi: (1) Pendahuluan, (2) Penetapan Masa jabatan Jaksa Agung berdasarkan aturan hukum yang berlaku, (3) Penetapan Masa jabatan Jaksa Agung berdasarkan Putusan Mahkamah Konstitusi Nomor 49/PUU-VIII/2010 Tentang Pengujian Undang-Undang Nomor 16 Tahun 2004 Tentang Kejaksaan RI aturan hukum yang berlaku, (4) Penetapan Masa Jabatan Jaksa Agung dalam Sistem Penetapan Jabatan Pejabat Negara, dan (5) Penutup.

${ }^{7}$ Menurut kesaksian Denny Indrayana, sebagai salah satu saksi ahli dari pihak pemerintah, dalam persidangan uji materi UU No. 16 Tahun 2004. Lihat putusan MK No.49/PUU-VII/2010.

$8<$ http://yusril.ihzamahendra.com/2010/08/27/permohonan-uji-materil-uu-Kejaksaanke-mk/>, diakses tanggal 1 Juli 2011. 


\section{Penetapan Masa Jabatan Jaksa Agung Berdasarkan Aturan Hukum yang Berlaku}

\section{Pengertian Penetapan Masa Jabatan}

Penetapan atau beschikking menurut S. Prajudi Atmosudirdjo dirumuskan sebagai perbuatan hukum sepihak yang bersifat administrasi negara yang dilakukan oleh pejabat atau instansi penguasa (negara) yang berwenang dan berwajib khusus untuk itu. ${ }^{9}$ Syarat utama bagi suatu penetapan adalah, bahwa tindak hukum atau perbuatan hukum (rechtschandeling) tersebut harus sepihak (eenzijdig) dan harus bersifat administrasi negara, artinya realisasi daripada suatu kehendak atau ketentuan undang-undang secara nyata kasual-individual. ${ }^{10}$

Semua penetapan yang diambil oleh Administrasi Negara dimuat atau dituangkan dalam suatu keputusan, dan pada umumnya keputusan dilakukan secara tertulis dan berbentuk surat keputusan atau sejenisnya. ${ }^{11}$ Misalnya Keputusan Tata Usaha Negara (KTUN) yaitu suatu penetapan tertulis yang dikeluarkan oleh badan atau Pejabat Tata Usaha Negara yang berisi Tindakan Hukum Tata Usaha Negara berdasarkan peraturan perundang-undangan yang berlaku, yang bersifat konkret, individual dan final, yang menimbulkan akibat hukum bagi seseorang atau badan hukum perdata. ${ }^{12}$ Contoh dari KTUN adalah Keputusan Presiden, Keputusan MPR dan lainnya.

Masa secara leksikologi berarti era, zaman, musim, tempo, atau saat. ${ }^{13}$ Sementara itu, jabatan berarti sekumpulan tugas dan tanggung jawab yang dibebankan oleh seorang pejabat yang berwenang kepada seseorang baik untuk waktu yang penuh maupun sebagian. Jabatan menunjukkan hal-hal yang dikerjakan, bukan orangnya. ${ }^{14}$ Dengan demikian masa jabatan dapat diartikan jangka waktu tertentu dalam melakasanakan tugas dan tanggungjawab yang diemban seorang pejabat. Istilah masa jabatan similar dengan masa bakti atau masa kerja.

${ }^{9}$ S. Prajudi Atmosudirdjo, "Hukum Administrasi Negara", (Jakarta: Ghalia Indonesia, 1994), hal. 94.

${ }^{10}$ Ibid.

${ }^{11}$ Philipus M. Hadjon, dkk., "Pengantar Hukum Administrasi Indonesia", (Yogyakarta: Gadjah Mada University Press, 1993), hal. 135. Usaha Negara.

${ }^{12}$ Lihat Pasal 1 angka 3 Undang-Undang Nomor 5 Tahun 1986 tentang Peradilan Tata

${ }^{13}$ Pius A. Partanto dan M. Dahlan Al Barry, "Kamus Ilmiah Populer", (Surabaya: Arkola, 2001), hal. 441.

${ }^{14}$ Patriata Westra (eds.), "Ensiklopedi Administrasi”, (Jakarta: CV. Haji Masagung, 1989), hal. 230. 


\section{Penetapan Masa Jabatan Jaksa Agung Menurut Peraturan Perundang-undangan yang berlaku}

Institusi Kejaksaan telah ada sejak masa sebelum Indonesia merdeka namun pasca kemerdekaan negara republik Indonesia belum memiliki UU khusus yang mengatur Kejaksaan sehingga berdasarkan Pasal II Aturan Peralihan UUD 1945 digunakanlah indische staatsregeling, semacam undang-undang dasar negeri jajahan Hindia Belanda. ${ }^{15}$ Berdasarkan konstitusi ini kedudukan Kejaksaan Agung berdampingan dengan Mahkamah Agung yang secara administratif berada di bawah Departemen Kehakiman, di bawah eksekutif, namun secara fungsional dalam menyelenggarakan peradilan bersifat independen. Jadi sejak awal kedudukan Kejaksaan memang berdiri di dua sisi, yudisial dan eksekutif, sehingga kemudian menimbulkan kontradiksi dalam pengaturannya (dual obligation). ${ }^{16}$ Pola kelembangaan ini terus dipakai pada masa Konstitusi RIS (1949-1950), masa demokrasi parlementer (1950-1959) dan berakhir pada masa demokrasi terpimpin (1959-1965). Pada masa ini Kejaksaan yang awalnya berstatus lembaga Nondepartemen di bawah Departemen Kehakiman menjadi lembaga yang berdiri sendiri, ${ }^{17}$ departemen tersendiri yang terpisah dari Departemen Kehakiman dan Mahkamah Agung, hingga saat ini.

Berdasarkan indische staatsregeling ini pula, Jaksa Agung adalah jabatan karir, bukan jabatan politik sehingga dalam prakteknya Jaksa Agung diangkat oleh Perdana Menteri atas usul Menteri Kehakiman. Pola ini kemudian berubah pada masa Konstitusi RIS, Jaksa Agung diangkat oleh Presiden atas usul Perdana Menteri, ${ }^{18}$ hingga timbulnya Dekrit Presiden 5 Juli 1959 yang disusul disahkannya UU No. 15 Tahun 1961.

Selama berada di bawah UUD 1945 pasca Dekrit Presiden 5 Juli 1959, dari ketiga undang-undang yang mengatur lembaga Kejaksaan yaitu UU No. 15 Tahun 1961, UU No. 5 Tahun 1991 dan UU No.16 Tahun 2004 kesemuanya mengatur bahwa Kejaksaan adalah lembaga pemerintah yang berada di dalam ranah kekuasaan eksekutif. ${ }^{19}$ UU No. 15 Tahun 1961 menegaskan bahwa Kejaksaan ialah "alat negara“, UU

${ }^{15}<$ http://yusril.ihzamahendra.com/2010/08/08/>, diakses tanggal 1 Juli 2011.

${ }^{16}$ Riri Nazriyah, Pemberhentian Jaksa Agung dan Hak Prerogatif Presiden, Jurnal Konstitusi, Vol. 7 No. 2 Oktober 2010 (Jakarta: Sekretariat Jenderal dan Kepaniteraan Mahkamah Konstitusi, 2010), hal. 30. Lihat juga Marwan Effendy, "Kejaksaan RI Posisi dan Fungsinya dari Perspektif Hukum”, (Jakarta: Gramedia, 2005), hal. 122.

${ }^{17}$ Marwan Effendy, "Kejaksaan RI Posisi dan Fungsinya dari Perspektif Hukum", (Jakarta: Gramedia, 2005), hal. 68.

${ }^{18}<$ http://yusril.ihzamahendra.com/2010/08/08/>, diakses tanggal 1 Juli 2011.

${ }^{19}$ Ibid. 
No. 5 Tahun 1991 dan UU No.16 Tahun 2004 menegaskan bahwa Kejaksaan adalah "lembaga pemerintah". Sementara itu ketiga UU tadi menetapkan Jaksa Agung adalah sebagai pembantu presiden karena diangkat dan diberhentikan oleh presiden dengan kedudukan setingkat menteri negara. ${ }^{20}$

Setelah akhir masa orde lama hingga berakirnya orde baru kewenangan mengangkat dan memberhentikan Jaksa Agung sepenuhnya menjadi kewenangan mutlak Presiden. Kemudian pada awal reformasi, demi independensi Kejaksaan dalam menjalankan tugasnya dari bayangbayang kepentingan politik presiden, diusulkan untuk mengadopsikan pengaturan mengenai Kejaksaan dalam BAB IX tentang Kekuasaan Kehakiman dalam amandemen UUD 1945 namun gagal mencapai kesepakatan. Demikian pula ketika RUU Kejaksaan 2004 dibahas, terjadi ketidaksepakatan antara pemerintah dan DPR. Akhirnya Jaksa Agung tetap sebagai Pejabat Negara yang diangkat dan diberhentikan oleh presiden namun dalam menjalankan fungsinya Kejaksaan bersifat merdeka. $^{21}$

Berikut dilakukan analisis terhadap penetapan masa jabatan Jaksa Agung berdasarkan undang-undang kejaksaan:

\section{a. Penetapan Masa Jabatan Jaksa Agung Menurut Undang- Undang Nomor 15 Tahun 1961 tentang Ketentuan- Ketentuan Pokok Kejaksaan (LN 1961 No. 254)}

Undang-Undang Nomor 15 Tahun 1961 tentang KetentuanKetentuan Pokok Kejaksaan (LN 1961 No. 254) memposisikan (kedudukan) kejaksaan sebagai alat negara penegak hukum yang terutama bertugas sebagai penuntut umum. Penegasan ini mengandung makna bahwa bila dilihat dari penaannya, sekalipun Kejaksaan sebagai alat penegak hukum bukan alat pemerintahan (eksekutif), namun bila dikaitkan dengan ketentuan Pasal 5 ayat (1) huruf a dan b UU ini bahwa penyelenggaraan tugas Departemen Kejaksaan dilakukan oleh Menteri dan Susunan organisasai Departemen Kejaksaan diatur dengan Keputusan Presiden, memperlihatkan bahwa posisi (kedudukan) Kejaksaan berada di bawah (di lingkungan) pemerintah (eksekutif/presiden). Departemen Kejaksaan dipimpin oleh seorang Menteri yang merupakan pembantu presiden, apalagi Departemen Kejaksaan ini diatur dalam suatu Keputusan Presiden.

${ }^{20}$ Marwan Effendy, Op. Cit., hal. 9.

${ }^{21}$ Jimly Asshiddiqie, "Perkembangan dan Konsolidasi Lembaga Negara Pasca Reformasi", (Jakarta: Sekretariat Jenderal dan Kepaniteraan MKRI, 2006), hal. 222. 


\section{b. Penetapan Masa Jabatan Jaksa Agung Menurut Undang- Undang Nomor 5 Tahun 1991 tentang Kejaksaan Republik Indonesia (LN 1991/59; TLN No. 3451)}

Undang-Undang Nomor 5 Tahun 1991 tentang Kejaksaan Republik Indonesia (LN 1991/59; TLN No. 3451) diundangkan pada tanggal 22 Juli 1991. Pada salah satu pertimbangan hukumnya ditentukan:

Bahwa kedudukan dan peranan kejaksaaan RI adalah sebagai lembaga pemerintahan yang melaksanakan kekuasaan negara di bidang penuntutan daam tata susunan kekuasaan badan-badan penegak hukum dan keadilan.

Penetapan Jaksa Agung diatur dalam Pasal 19 yang menetapkan bahwa jaksa agung diangkat dan diberhentikan oleh serta bertanggungjawab kepada presiden. Selanjutnya dalam Pasal 21 ayat (4) ditetapkan, bahwa wakil jagung dan jagung muda diberhentikan dengan hormat dari jabatannya karena:
a. permintaan sendiri; atau
b. sakit jasmani atau rohani terus menerus; atau
c. telah berumur 60 (enam puluh) tahun; atau
d. ternyata tidak cakap menjalankan tugas; atau
e. meninggal dunia.

Berdasarkan ketentuan Undang-Undang Nomor 5 Tahun 1991 tentang Kejaksaan Republik Indonesia, maka pada dasarkan tidak mengatur mengenai pemberhentian jaksa agung, hal ini tentunya berbeda dengan keberdaan wakil jaksa agung dan jaksa agung yang secara limitatif ditentukan masa jabatannya.

\section{c. Penetapan Masa Jabatan Jaksa Agung Menurut Undang- Undang Nomor 16 Tahun 2004 tentang Kejaksaan Republik Indonesia}

Undang-Undang Nomor 16 Tahun 2004 tentang Kejaksaan RI, merupakan UU yang sekarang berlaku. Berdasarkan Pasal 2 Ayat (1) UU No.16 Tahun 2004, ditentukan bahwa kedudukan Kejaksaan adalah: (a) sebagai lembaga pemerintah (eksekutif), (b) sebagai pelaksana kekuasaan negara di bidang penuntuta, dan (c) sebagai pelaksana kewenangan lain berdasarkan undang-undang. ${ }^{22}$ Selanjutnya Pasal 2 Ayat (2), menegaskan bahwa Kekuasaan (kewenangan) penuntutan dan kewenangan lain itu dilaksanakan secara merdeka. Artinya dalam melaksanakan fungsi, tugas, dan 
wewenangnya terlepas dari pengaruh kekuasaan pemerintah dan pengaruh kekuasaan lainnya. ${ }^{23}$

Pasal 2 Ayat (3) UU ini menyatakan bahwa Kejaksaan adalah satu dan tidak terpisahkan. Artinya Kejaksaan memiliki satu landasan dalam pelaksanaan tugas dan wewenangnya di bidang penuntutan yang bertujuan memelihara kesatuan kebijakan dibidang penuntutan sehingga dapat menampilkan ciri khas yang menyatu dalam tata pikir, tata laku, dan tata kerja Kejaksaan. Oleh karena itu kegiatan penuntutan di pengadilan oleh Kejaksaan tidak akan berhenti hanya karena jaksa yang semula bertugas berhalangan. Dalam hal demikian tugas penuntutan oleh Kejaksaan akan tetap berlangsung sekalipun untuk itu dilakukan oleh jaksa lainnya sebagai pengganti. ${ }^{24}$

Kejaksaan sebagai lembaga pemerintah terdiri atas Kejaksaan Agung, Kejaksaan Tinggi dan Kejaksaan Negeri. Kejaksaan Agung berkedudukan di ibu kota negara dan daerah hukumnya meliputi seluruh wilayah kekuasaan Negara Republik Indonesia.

Berkaitan dengan penetapan masa jabatan Jaksa Agung diatur dalam Pasal 22 Ayat (1) UU No. 16 Tahun 2004 tentang Kejaksaan RI yang menegaskan:
Jaksa Agung diberhentikan dengan hormat dari jabatnnya karena:
a. meninggal dunia;
b. permintaan sendiri;
c. sakit jasmani atau rohani terus-menerus;
d. berakhir masa jabatannya;
e. tidak lagi memenuhi salah satu syarat sebagaimana dimaksud dalam Pasal 21.

Berdasarkan perundang-undangan yang pernah ada mulai Undang-Undang Nomor 15 Tahun 1961, Undang-Undang Nomor 5 Tahun 1991 dan Undang-Undang Nomor 16 Tahun 2004 pada dasarnya tidak ada yang mengatur secara definitif dan limitatif berapa lama seorang Jaksa Agung menduduki jabatannya.

\section{Penetapan Masa Jabatan Jaksa Agung RI Berdasarkan Putusan Mahkamah Konstitusi Nomor 49/PUU-VIII/2010 Tentang Pengujian Undang-Undang Nomor 16 Tahun 2004 Tentang Kejaksaan RI}

Pasal 22 Ayat (1) Huruf d UU No. 16 Tahun 2004 tentang Kejaksaan menegaskan sebagai berikut:

\footnotetext{
${ }^{23}$ Penjelasan Pasal 2 Ayat (2) UU No.16 Tahun 2004 tentang Kejaksaan RI.

${ }^{24}$ Penjelasan Pasal 2 Ayat (2), Ibid.
} 
Jaksa Agung diberhentikan dengan hormat dari jabatnnya karena:

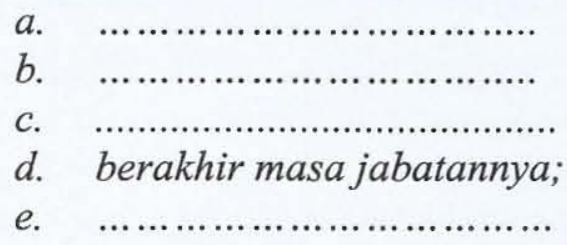

Tidak ada penjelasan secara limitatif dari ketentuan Pasal 22 Ayat (1) Huruf d UU No. 16 Tahun 2004 tentang Kejaksaan. Artinya, bilakah berakhirnya masa jabatan Jaksa Agung tersebut tidak ditentukan secara pasti. Menurut Yusril Ihza Mahendra klausul huruf d tersebut tidak jelas sehingga multitafsir (polyinterpretabel) karena tidak menjelaskan dengan pasti kapan seorang Jaksa Agung dianggap berakhir masa jabatannya. Klausul itu dapat saja ditafsirkan seumur hidup ${ }^{25}$ selama tidak diberhentikan dan sebagainya. Hal ini dapat menimbulkan ketidakpastian hukum (rechsonzekerheid). Selaku warga Negara Yusril merasa dirugikan akibat ketentuan Pasal 22 Ayat (1) Huruf d UU No. 16 Tahun 2004 tentang Kejaksaan sehingga Yusril mengajukan permohon agar MK sebagai the guardian of constitution dan the final interpreter of the constitution agar memberikan tafsir yang pasti.

Erman Rajagukguk, Margarito Kamis dan Andi Muhammad Asrun yang ditunjuk sebagai saksi ahli dalam persidangan judicil review Pasal 22 Ayat (1) huruf d UUK 2004 berpendapat bahwa pada dasarnya Jaksa Agung sebagai pejabat negara setingkat menteri ataupun sebagai anggota kabinet berakhir bersamaan dengan berakhirnya masa jabatan anggota kabinet lainnya. ${ }^{26}$

Bagir Manan berpendapat:

Jaksa Agung sebagai Jaksa berakhir masa jabatannya karena memasuki usia pensiun. Sementara Jaksa Agung sebagai pejabat setingkat Menteri Negara dan anggota kabinet, maka jabatannya itu berakhir bersama-sama dengan anggota kabibet yang lain. Merujuk kepada Keppres Nomor 187/M Tahun 2004 dan Keppres Nomor 31/P Tahun 2007, maka jabatan Hendarman Supandji telah berakhir pada tanggal 20 Oktober 2009. Sejak itu dia menduduki jabatan itu secara tidak sah. Segala tindakan yang dilakukan oleh pejabat yang tidak sah, tidaklah membawa akibat hukum. ${ }^{27}$

${ }^{25}$ Menurut kesaksian Denny Indrayana dan Achmad Roestandi, sebagai salah satu saksi ahli dari pihak pemerintah, dalam persidangan uji materi UU No. 16 Tahun 2004. Lihat putusan MK No.49/PUU-VII/2010.

${ }^{26}$ Pendapat Erman Rajagukguk, Margarito Kamis dan Andi Muhammad Asrun ini disampaikan pada saat mereka menjadi saksi ahli dari pihak pemohon pada persidangan uji materi UU No. 16 Tahun 2004.

${ }^{27}$ Pendapat Bagir Manan yang disampiakan pada saat mereka menjadi saksi ahli dari pihah pemohon pada persidangan uji materi UU No. 16 Tahun 2004 


\section{Selanjutnya menurut Laica Marzuki:}

Jaksa Agung adalah publieke ambt atau jabatan publik. Mengutip Prof. Logemann, jabatan adalah person pribadi hukum yang bersifat abstrak yang tidak dapat menjalankan fungsi dan kewenangannya. Karena itu ia harus diwakili oleh pemegang jabatan atau ambtsdrager. Jabatan bersifat langgeng dan abadi, sementara pemegang jabatan atau ambtsdrager datang dan pergi silih berganti. Masa jabatan Hendarman Supandji berdasarkan Keppres Nomor 187/M Tahun 2004 berakhir pada tanggal 20 Oktober 2009. Namun sejak itu dia tidak pernah diangkat kembali, baik sebagai Jaksa Agung yang menjadi anggota kabinet maupun di luar kabinet. Dengan demikian, Hendarman telah mewakili jabatan het ambt Jaksa Agung secara terus-menerus dengan masa jabatan yang tak kunjung berakhir. Ini semua akibat multitafsir ketentuan Pasal 22 Ayat (1) huruf d UU Kejaksaan, yang mencederai asas kedaulatan rakyat dan asas kepastian hukum di dalam UUD $1945 .^{28}$

\section{H.A.S. Natabaya:}

Ketentuan Pasal 22 Ayat (1) huruf d UU Nomor 16 Tahun 2004 bertentangan dengan asas beginselen van behoorlijk regelgeving atau asas pembentukan perundang-undangan yang baik, sebagaimana juga diatur dalam Pasal 6 UU Nomor 10 Tahun 2004 tentang Pembentukan Peraturan Perundang-Undangan. Ketentuan ini tidak memenuhi syarat adanya kepastian hukum. ${ }^{29}$

Berbeda dengan pendapat terebut di atas, M. Fadjrul Falakh berpendapat:

UU No.16 Tahun 2004 memang tidak mengatur masa jabatan Jaksa Agung sebagai pejabat negara. Jabatan Jaksa Agung tidak dapat dikaitkan dengan masa jabatan sebagai anggota kabinet, karena Jaksa Agung tidak boleh merangkap pejabat negara yang lain, termasuk merangkap jabatan menjadi menteri. Jabatan Jaksa Agung termasuk jabatan publik sehingga mengenai pengangkatan dan pemberhentiannya bergantung kepada keputusan politik dari pejabat yang berwenang (Presiden). Menurut kaidah TUN, tindakan tidak menerbitkan surat keputusan tentang sesuatu harus diartikan bahwa pejabat TUN tersebut telah memutus sesuai tindakan yang tidak dituangkan dalam suatu surat atau dokumen tertulis. Hal tersebut merupakan presumption of legality. ${ }^{30}$

\footnotetext{
${ }^{28}$ Pendapat Laica Marzuki yang disampiakan pada saat mereka menjadi saksi ahli dari pihak pemohon pada persidangan uji materi UU No. 16 Tahun 2004

${ }^{29}$ Pendapat H.A.S. Natabaya yang disampiakan pada saat mereka menjadi saksi ahli dari pihak pemohon pada persidangan uji materi UU No. 16 Tahun 2004
} 
Pendapat M. Fadjrul Falakh mendapat dukungan dari beberapa ahli hukum antara lain Philipus Hadjon, Andan Buyung Nasution dan Denny Indrayana selaku saksi ahli dari pihak pemerintah.

MK dalam pertimbangan hukumnya menerima pendapat saksi ahli, HAS Natabaya, bahwa UUK 2004 tidak memenuhi asas-asas umum pembentukan perundang-undangan yang baik (algemene beginselen van behoorlijke regelgeving) yang sejalan dengan asas-asas umum penyelenggaraan pemerintahan yang baik (algemene beginselen van behoorlijke bestuur, the general principle of good administration $)^{31}$ karena adanya inkonsistensi antara Pasal 19 UUK 2004 dan Pasal 22 Ayat (1) huruf d. Pendapat MK menyatakan bahwa:

Jaksa Agung sebagai Pejabat Negara seharusnya diberhentikan dengan hormat dari jabatannya oleh Presiden berdasarkan kondisi yang pasti, yaitu, jika ia meninggal dunia, atas permintaan sendiri, atau karena sakit jasmani dan rohani terus menerus, namun demikian tentang kapan "berakhir masa jabatannya" merupakan kondisi yang tidak menentu. ${ }^{32}$

Oleh karena itu pokok masalahnya adalah pada proses pembentukan UU a quo. MK berpendapat:

... permasalahan penafsiran terhadap Pasal 22 ayat (1) hurufd UU 16/2004 yang menyatakan "Jaksa Agung diberhentikan dengan hormat dari jabatannya karena:... d. berakhir masa jabatannya" bukanlah masalah konstitusionalitas norma yang merupakan lingkup ranah judicial review yang menjadi wewenang Mahkamah, tetapi lebih merupakan lingkup ranah legislative review yang menjadi wewenang pembentuk undang-undang, yaitu DPR dan Presiden. Akan tetapi masalah konstitusionalitas timbul ketika frasa ini bersifat multitafsir sehingga menimbulkan ketidakpastian hukum, termasuk ketidakpastian hukum dalam hal kedudukan di hadapan hukum.

Atinya MK menyatakan tetap berwenang mengadili perkara ini. Selanjutnya menurut MK paling tidak ada empat alternatif untuk menentukan kapan mulai diangkat dan saat berhentinya pejabat negara menduduki jabatannya in casu Jaksa Agung, yaitu: (a) berdasar periodisasi Kabinet dan/atau periode masa jabatan Presiden yang mengangkatnya, (b) berdasar

${ }^{30}$ Pendapat H.A.S. Natabaya yang disampiakan pada saat mereka menjadi saksi ahli dari pihak termohon (Pemerintah) pada persidangan uji materi UU No. 16 Tahun 2004.

${ }^{31}$ Putusan MK No. 49/PUU-VIII/2010, hal. 130.

${ }^{32}$ Ibid. 
periode (masa waktu tertentu) yang fixed tanpa dikaitkan dengan jabatan politik di kabinet, (c) berdasarkan usia atau batas umur pensiun, (d) berdasarkan diskresi Presiden/pejabat yang mengangkatnya.

Terkait hal ini MK menyatakan:

Oleh karena ternyata tidak ada satu pun dari alternatif tersebut yang secara tegas dianut dalam UU a quo, maka menurut Mahkamah, ketentuan "karena berakhir masa jabatannya" ... itu memang menimbulkan ketidakpastian hukum. Mahkamah berpendapat pula bahwa karena ketidakpastian hukum itu bertentangan dengan konstitusi maka seharusnya pembentuk Undang-Undang segera melakukan legislative review untuk memberi kepastian dengan memilih salah satu dari alternatifalternatif tersebut. Namun karena legislative review memerlukan prosedur dan waktu yang relatif lama, maka sambil menunggu langkah tersebut Mahkamah memberikan penafsiran sebagai syarat konstitusional (conditionally constitutional) untuk berlakunya Pasal 22 ayat (1) huruf d UU 16/2004 tersebut yang dinyatakan berlaku prospektif sejak selesai diucapkannya putusan ini $^{33}$

MK juga menyatakan “... dalam praktik ketatanegaraan yang berlangsung selama ini, penetapan masa jabatan secara tegas telah digunakan dalam beberapa jabatan publik. ...”. penaturan yang tegas tersebut dapa ditemukan misalnya pada Pasal 7 UUD 1945, Undang-Undang KY, KPK, MK dan MA.

Dengan mempertimbangkan semua bukti-bukti persidangan dan keterangan-keterangan sanksi ahli akhirnya dalam amar putusan MK menyatakan Pasal 22 ayat (1) huruf d UU No. 16 Tahun 2004 tentang Kejaksaan RI adalah sesuai dengan UUD 1945, oleh karena itu mempunyai kekuatan hukum mengikat, secara bersyarat (conditionally constitutional), yaitu konstitusional sepanjang dimaknai "masa jabatan Jaksa Agung itu berakhir dengan berakhirnya masa jabatan Presiden Republik Indonesia dalam satu periode bersama-sama masa jabatan anggota kabinet atau diberhentikan dalam masa jabatannya oleh Presiden dalam periode yang bersangkutan", ${ }^{34}$ artinya Jaksa agung dapat diberhentikan sewaktu-waktu dalam masa tugas oleh presiden.

Di lingkungan Mahkamah Konstitusi dikenal adanya empat bentuk produk hukum, yaitu: (i) putusan (vonnis), (ii) peraturan (regels), (iii) ketetapan (beschikking) di bidang administrasi justisial, dan (iv) keputusan (beschikking) di bidang administrasi umum. ${ }^{35}$

${ }^{33}$ Ibid., hal. 133.

${ }^{34}$ Putusan MK No. 49/PUU-VIII/2010, 134. 
Mengenai putusan, berdasarkan Pasal 56, Pasal 57, Pasal 64, Pasal 70, Pasal 77, dan Pasal 83 UU No. 24 Tahun 2003 tentang MK hanya dikenal 4 jenis putusan, yaitu dikabulkan, ditolak, tidak dapat diterima, dan putusan membenarkan pendapat DPR mengenai telah terjadinya pelanggaran konstitusional oleh Presiden dan/atau Wakil Presiden. Namun dalam prakteknya putusan MK telah bermutasi menjadi pelbagai jenis putusan. Terdapat putusan MK berupa konstitusional bersyarat (conditionally constitutional), tidak konstitusional bersyarat (conditionally unconstitutional), dan putusan sela. ${ }^{36}$

Dalam kaitannya dengan pengujian UU terhaap UUD 1945 putusan MK hanya mengenal 3 (tiga) jenis putusan, yaitu ditolak, tidak dapat diterima dan dikabulkan.

a. Pemohonan ditolak, apabila undang-undang yang dimohonkan untuk diuji tidak bertentangan dengan UUD 1945, baik mengenai pembentukan (formil) maupun materinya untuk sebagian atau keseluruhan.

b. Tidak Dapat Diterima (niet ontvankelijk verklaard), apabila pemohon dan/atau permohonannya tidak memenuhi syarat kedudukan hukum (legal standing) untuk berperkara di Mahkamah Konstitusi.

c. Dikabulkan, apabila permohonan dinyatakan beralasan, dimana materi muatan ayat, pasal, dan/atau bagian dari undang-undang bertentangan UUD 1945 atau proses pembentukan UU yang bersangkutan tidak dilakukan sesuai prosedur pembentukan dan/atau oleh lembaga yang telah ditentukan oleh UUD dan/atau UU yang berlaku. ${ }^{37}$

Meskipun demikian, lagi-lagi dalam kenyataannya, berdasarkan amar putusannya terdapat 6 jenis putusan MK, yaitu: (a) dikabulkan, (b) dikabulkan keseluruhan, (c) dikabulkan untuk sebagian, (d) ditolak, (e) ditolak (dengan syarat konstitusionalitas tertentu), dan (f) tidak dapat diterima. ${ }^{38}$

Dari keenam jenis amar putusan tadi yang unik adalah putusan MKyang amar putusannya "ditolak" tetapi dalam pertimbangan hukumnya memberikan syarat konstitusionalitas atau menyatakan konstitusionalitas bersyarat (conditionally constitutional) pada salah satu ketentuan dalam UU.

35 Jimly Asshiddiqie, "Hukum Acara Pengujian Undang-Undang", (Jakarta: Konpress, 2006), hal. 280.

36 Perkembangan Pengujian Perundang-Undangan di Mahkamah Konstitusi dari Berpikir Hukum Tekstual Ke Hukum Progresif, Hasil Penelitian Pusat Studi Konstitusi (PUSaKO) Fakultas Hukum Universitas Andalas, 2010, hal. 1.

${ }^{37}$ Tim Penyusun Buku Enam Tahun MK, "Enam Tahun Mengawal Konstitusi dan Demokrasi; Gambaran Singkat Pelaksanaan Tugas Mahkamah Konstitusi 2003-2009", (Jakarta: Sekretariat Jenderal dan Kepaniteraan MK, 2008), hal. 545.

$38<\mathrm{http}$ //yancearizona.wordpress.com/2008/11/12/dibalik-konstitusionalitas-bersyaratputusan-mahkamah-konstitusi/>, diakses tanggal 26 Juli 2011. 
Putusan-putusan MK yang dalam amar putusannya menggunakan kalausul konstitusion bersyarat (conditionally constitutional) didasarkan pada pertimbangan hukum (ratio decidendi) bahwa permohonan yang dimohonkan uji tidak dapat diputus berdasarkan 3 jenis putusan yang telah diatur dalam UU MK namun permohonan tersebut beralasan. Dan penyelesaian perkara yang dimohonkan uji tersebut sebenarnya lebih tepat dilakukan melaui proses legislative review oleh pembentuk undang-undang, dalam hal ini DPR bersama presiden, bukan melalui judicial review oleh MK. Namun karena legislative review memerlukan prosedur dan waktu yang relatif lama, maka sambil menunggu langkah tersebut mahkamah tetap memutus dengan memberikan penafsiran sebagai syarat konstitusional (conditionally constitutional) untuk berlakunya suatu norma yang dimohonkan uji. Dengan demikian mahkamah telah merumuskan norma baru yang sebelumnya tidak dikenal dalam ilmu hukum dan hal inilah yang dinamakan penemuan hukum (rechtsvinding). Hal ini adalah dalam rangka menegakkan keadilan substantif yang oleh UUD 1945, UU, prinsip-prinsip umum konstitusi dan peradilan diakui keberadaannya, ${ }^{39}$ yang dalam istilah mahfud $\mathrm{MD}$ disebut hukum progresif. $^{40}$

Dalam Glosarium Buku Enam Tahun MK disebutkan makna conditionally constitutional, yaitu:

Konstitusional bersyarat, artinya suatu muatan norma dianggap konstitusional (tidak bertentangan dengan Konstitusi) bila dimaknai sesuai dengan yang ditentukan $M K^{41}$

Konstitusionalitas bersyarat (conditionally constitutional) dalam putusan MK adalah putusan yang menyatakan bahwa suatu ketentuan UU tidak bertentangan dengan konstitusi dengan memberikan persyaratan kepada lembaga negara dalam pelaksanaan suatu ketentuan UU untuk memperhatikan penafsiran MK atas konstitusionalitas ketentuan UU yang sudah diuji tersebut. Apabila syarat tersebut tidak dipenuhi atau ditafsirkan lain oleh lembaga negara yang melaksanakannya, maka ketentuan undang-undang yang sudah diuji tersebut dapat diajukan untuk diuji kembali oleh MK. ${ }^{42}$

Menurut Jimly Asshiddiqie suatu norma dikatakan konstitusional bersyarat (conditionally constitutional) apabila konstitusionalitasnya digantungkan salah satu alasan hukum berikut:

a. tafsir dan penafsiran atas norma tertentu itu menurut apa yang dijadikan dasar pertimbangan (ratio decidendi) dalam putusan MK;

${ }^{39}$ MKRI, Mengawal Demokrasi Menegakkan Keadilan Substantif; Refleksi Kinerja MK 2009 Proyeksi 2010, (Jakarta, 29 Desember 2009), 5

${ }^{40}$ PuSaKo, Op. Cit., hal. 2.

${ }^{41}$ Tim Penyusun Buku Enam Tahun MK, Op. Cit., hal. 543.

${ }^{42}<$ http://yancearizona.wordpress.com/2008/11/12/>, diakses tanggal 11 Juni 2008. 
b. pelaksanaan lebih lanjut atas norma itu dalam peraturan pelaksanaannya lebih lanjut yang masih akan ditetapkan oleh pelaksana UU yang bersangkutan;

c. digantungkan pada praktik penerapannya kelak di kemudian hari yang harus benar-benar sesuai dengan substansi pertimbangan putusan MK yang membenarkan norma UU yang bersangkutan. ${ }^{43}$

Istilah conditionally constitutional pertama kali diperkenalkan MK dalam putusan perkara No. 058-059-060-063/PUU-II/2004 dan 008/PUU-III/2005 mengenai Pengujian UU Sumberdaya Air (UU No. 7/2004). ${ }^{44}$ Kemudian setelah itu Mahkamah Konstitusi mengadopsi klausul tersebut dalam beberapa putusannya.

Terkait istilah "conditionally constitutional", menurut Jimly Asshiddiqie belum ada kajian khusus dalam bentuk buku yang mengkaji tentang masalah tersebut. Istilah ini baru muncul dalam perkembangan penemuan hukum (rechtsvinding) dalam praktik di MK selama 5 (lima) tahun terakhir. ${ }^{45}$

\section{Penetapan Masa Jabatan Jaksa Agung dalam Sistem Penetapan Jabatan Pejabat Negara}

Istilah Pejabat Negara berdasarkan Undang-Undang Nomor 28 Tahun 1999 tentang Penyelenggaraan Negara Yang Bersih dan Bebas dari Korupsi, Kolusi dan Nepotisme Bab I Ketentuan Umum Pasal 1 angka 1, dinyatakan Penyelengara Negara adalah pejabat Negara yang menjalankan fungsi eksekutif, legislatif, atau yudisial ....". Selanjutnya Pasal 2 menyatakan, bahwa "Penyelenggara Negara meliputi:

1. Pejabat Negara pada Lembaga Tertinggi Negara; ${ }^{46}$

2. Pejabat Negara pada Lembaga Tinggi Negara;

3. Menteri;

4. Gubernur;

5. Hakim;

6. Pejabat Negara lain ....";

7. Pejabat lain ......

Berdasarkan tersebut dapatlah disimpulkan bahwa yang dimaksud dengan Pejabat Negara adalah:

${ }^{43}<$ http://www.jimly.com/tanyajawab?page=977>, diakses tanggal 14 Mei 2010.

${ }^{44}<\mathrm{http}$ ://yancearizona.wordpress.com/2008/11/12/>, diakses tanggal 3 Agustus 2009.

${ }^{45}<$ http://www.jimly.com/tanyajawab?>, diakses tanggal 8 Mei 2008.

${ }^{46}$ Setelah perubahan UUD 1945 dalam ketatanegaraan dan sistem pemerintahan di Indonesia tidak dikenal lagi Lembaga Tertinggi Negara. 
(1)Pejabat yang duduk pada Lembaga Tinggi Negara yang setelah amandemen UUD 1945 meliputi: (a) lembaga eksekutif yaitu Presiden dan Wakil Presiden; (b) lembaga legislative MPR, DPR, DPD; (c) lembaga yudisial yaitu: MA, MK, KY, dan (d) lembaga eksaminatif BPK;

(2)Menteri, Gubernur dan Hakim.

(3)Pejabat Negara lain menurut ketentuan perundang-undangan misalnya Kepala Perwakilan RI di luar negeri yang berkedudukan sebagai Duta Besar Luar Biasa dan Berkuasa Penuh, Wakil Gubenur dan Bupati/Wali Kota.

(4)Pejabat lain seperti Direksi BUMN, BUMD, Pimpinan BI, Pimpinan PTN, Pejabat Eselon I, Jaksa, Penyidik, Panitera \& Pemimpin/ Bendaharawan Proyek.

Pejabat negara adalah pimpinan dan anggota lembaga tertinggi/tinggi negara sebagaimana dimaksud dalam Undang-Undang Dasar 1945 dan Pejabat Negara lainnya yang ditentukan oleh Undang-undang. Pejabat Negara terdiri atas:

a. Presiden dan Wakil Presiden;

b. Ketua, Wakil Ketua, dan Anggota Majelis Permusyawaratan Rakyat;

c. Ketua, Wakil Ketua, dan Anggota Dewan Perwakilan Rakyat;

d. Ketua, Wakil Ketua, Ketua Muda, dan Hakim Agung pada Mahkamah Agung, serta Ketua, Wakil Ketua dan Hakim pada pada semua Badan Peradilan;

e. Ketua, Wakil Ketua, dan Anggota Dewan Pertimbangan Agung;

f. Ketua, Wakil Ketua, dan Anggota Badan Pemeriksa Keuangan;

g. Menteri dan jabatan yang setingkat menteri;

h. Kepala Perwakilan Republik Indonesia di luar negeri yang berkedudukan sebagai Duta Besar Luar Biasa dan Berkuasa Penuh;

i. Gubernur dan Wakil Gubernur;

j. Bupati/Walikota dan Wakil Bupati/Wakil Walikota.

Dalam Undang-Undang Nomor 8 tahun 1974 tentang Pokok-Pokok Kepegawaian dikenal 2 (dua) jenis jabatan yakni jabatan negara dan jabatan negeri. Menurut Badan Administrasi Kepegawaian Negara, untuk menghadapi dinamika perkembangan politik dan pemerintahan, perlu adanya perluasan jabatan negara serta tambahan jabatan pada lembaga swadana dan perushaan milik negara (lembaga pendidikan tinggi, lembaga pelayanan kesehatan, lembaga litbang, lembaga diklat, badan otorita, serta badan usaha milik negara). ${ }^{47}$ Undang-Undang Nomor 43 tahun 1999 tentang Perubahan Atas Undang-Undang Nomor 8 tahun 1974 tentang Pokok-Pokok Kepegawaian, melakukan reformasi terhadap penyelenggaraan pelayananan

${ }^{47}$ Badan Administrasi Kepegawaian Negara, "Kebijakan Kepegawaian Negara dalam Rangka Penyelenggaraan Pemerintahan Pasca Pemilu 1999”, Bahan Presentasi pada Rakernas Depdikbud, 17 Mei 1999 di Jakarta, 17 Mei 1999, hal. 7. 
publik, dengan melakukan pembaharuan dalam struktur kepegawaian negara dengan menetapkan adanya tiga jenis jabatan pada kepegawaian negara yakni: jabatan negara, jabatan negeri dan jabatan pada lembaga swadana dan perusahaan milik negara.

Berbeda dengan Undang-Undang Nomor 28 Tahun 1999 tentang Penyelenggaraan Negara Yang Bersih dan Bebas dari Korupsi, Kolusi dan Nepotisme maupun Undang-Undang Nomor 43 tahun 1999 tentang Perubahan Atas Undang-Undang Nomor 8 tahun 1974 tentang Pokok-Pokok Kepegawaian, dalam Undang-Undang Nomor 14 Tahun 2008 tentang Keterbukaan Informasi Publik, digunakan istilah pejabat publik untuk menunjuk pejabat negara. Pasal 1 Angka 8 Undang-Undang Nomor 14 Tahun 2008 tentang Keterbukaan Informasi Publik, menyatakan pejabat Publik adalah orang yang ditunjuk dan diberi tugas untuk menduduki posisi atau jabatan tertentu pada badan publik. ${ }^{48}$ Sementara Badan Publik adalah lembaga eksekutif, legislatif, yudikatif, dan badan lain yang fungsi dan tugas pokoknya berkaitan dengan penyelenggaraan negara, yang sebagian atau seluruh dananya bersumber dari APBN dan/atau APBD, atau organisasi nonpemerintah sepanjang sebagian atau seluruh dananya bersumber dari APBN dan/atau APBD, sumbangan masyarakat, dan/atau luar negeri. ${ }^{49}$ Dalam Hukum Tata Negara dan Hukum Administrasi Negara istilah "Pejabat Publik" memiliki makna yang similar dengan istilah "Pejabat Tata Usaha Negara". 50

Dalam praktek ketatanegaraan Negara Republik Indonesia terdapat aturan-aturan yang tegas mengenai sistem penetapan masa jabatan pejabat publik. Berikut disajikan beberapa sistem pengaturan penetapan masa jabatan pejabat publik.

\section{Masa jabatan Presdien dan wakil Presiden}

Masa jabatan Presiden dan Wakil Presiden, diatur dalam Pasal 7 UUDNRI 1945 yang menegaskan bahwa Presiden dan Wakil Presiden memegang jabatan selama lima tahun dan sesudahnya dapat dipilih kembali dalam jabatan yang sama, hanya untuk satu kali masa jabatan.

Penetapan masa jabatan Presiden selama 5 (lima) tahun ini juga berlaku bagi kebanyakan negara-negara Eropa atau negara-negara di dunia yang menganut sistem hukum Eropa Kontinental (civil law), sementara bagi kebanyakan penganut sistem anglo saxon (common law) seperti Amerika Serikat, ${ }^{51}$ Australia, Inggris dan negara-negara

${ }^{48}$ Lihat Pasal 1 Angka 8 Undang-Undang Nomor 14 Tahun 2008 tentang Keterbukaan Informasi Publik.

49 Pasal 1 angka 3 Undang-Undang Nomor 14 Tahun 2008 tentang Keterbukaan Informasi Publik.

${ }^{50}$ Lihat Pasal 1 Angka 1 Undang-Undang Nomor 5 Tahun 1986 junto Undang-Undang Nomor 9 Tahun 2004 tentang Peradilan Tata Usaha Negara. 
persemakmuran Inggris (Malaysia, Philipina dan lainnya) menetapkan masa jabatan untuk Presiden selama 4 (empat) tahun.

\section{Penetapan Masa Jabatan Anggota Komisi Yudisial}

Masa jabatan anggota Komisi Yudisial, diatur dalam Pasal 29 Undang-Undang Nomor 22 Tahun 2004 tentang Komisi Yudusial (LN 2004 No. 89, TLN No. 4415) yang menegaskan bahwa anggota Komisi Yudisial memegang jabatan selama masa 5 (lima) tahun dan sesudahnya dapat dipilih kembali untuk 1 (satu) kali masa jabatan. Penetapan masa jabatan ini bebeda-beda untuk setiap negara yang konstitusinya mengadopsi lembaga Komisi Yudisial atau sejenisnya. Di Eropa Selatan sebagaimana hasil penelitian Wim Voermans, Perancis menetapkan masa jabatan anggota KY (Conseil superieur de la magistrature/CSM) selama 4 tahun, dan Spanyol menetapkan masa jabatan anggota KY (El Consejo General del Poder Judicial) untuk kurun waktu 5 (lima) tahun, ${ }^{52}$ dan Italia menetapkan masa jabatan anggota KY (Consiglio Superiore della Magistratura) kecuali anggota tetap yaitu Presiden, Ketua MA dan Jaksa Agung diangkat untuk masa 4 (empat) tahun. ${ }^{53}$ Sementara negara-negara Eropa Utara rata-rata menetapkan masa jabatan anggota $\mathrm{KY}$, seperti KY di Denmark (Domstolsstyrelsen) untuk kurun waktu 4 (empat) tahun. ${ }^{54}$

\section{Penetapan Masa Jabatan Hakim Konstitusi}

Masa jabatan Hakim Konstitusi, diatur dalam Pasal 22 dan Pasal 23 Ayat (1) huruf c dan huruf d Undang-Undang Nomor 24 Tahun 2003 tentang Mahkamah Konstitusi (LN 2003 No. 98, TLN No. 4316) yang menyatakan bahwa masa jabatan Hakim Konstitusi selama 5 (lima) tahun dan dapat dipilih kembali hanya untuk 1 (satu) kali masa jabatan berikutnya atau masa jabatan tersebut berakhir karena memasuki usia pensiun, yaitu 67 tahun.

Penetapan masa jabatan Hakim Konstitusi ini berbeda-beda bagi beberapa negara yang dalam konstitusinya mengadopsi lembaga Mahakmah Konstitusi dalam sistem ketatanegaraan. Republik Federal Jerman menetapkan masa jabatan Hakim Konstitusi pada lembaga Mahakmah Konstitusi (ver) selama 12 tahun dan setelahnya tidak dapat

${ }^{51}$ Pasal I ayat (1) Bagian II UUD Amerika Serikat menyatakan, Kekuasaan Eksekutif berada dalam tangan Presiden dari Amerika Serikat. Ia memangku jabatannya selama masa empat tahun dan bersama-sama dengan Wakil Presiden, dipilih untuk masa jabatan yang sama ....

${ }^{52}$ Wim Voermans, Raden voor de Rechtpraak in landen van de Europese Unie, Terj. Adi Nugroho dan M. Zaki Hussein, 2002, Jakarta: LeIP, hal. 12.

${ }^{53}$ Ibid., hal. 91-92.

${ }^{54}$ Ibid., hal. 56. 
dipilih kembali, ${ }^{55}$ Perancis menetapan masa jabatan Hakim Konstitusi pada Dewan Konstitusi selama 9 tahun dan setelahnya tidak dapat dipilih kembali, ${ }^{56}$ sementara Afrika Selatan masa jabatan hakim ditetapkan 12 tahun dan memasuki usia purna bhakti jika mencapai usia 70 tahun, ${ }^{57}$ dan Korea Selatan menetapkan masa jabatan hakim konstitusi selama 9 tahun dan setelah itu tidak dapat dipilih $\mathrm{kembali}^{58}$ dan memasuki usia pensiun pada usia 70 tahun bagi hakim Ketua (Ketua MK) dan 65 tahun bagi hakim anggota. ${ }^{59}$

\section{Penetapan Masa Jabatan Hakim Agung}

Masa jabatan Hakim Agung, diatur dalam Pasal 11 huruf $\mathrm{b}$ UndangUndang Nomor 3 Tahun 2009 tentang Perubahan Kedua Undang-Undang Nomor 14 Tahun 1985 tentang Mahkamah Agung (LN 2009 No. 3, TLN. 4958) yang mengatur bahwa masa jabatan Hakim Agung ditentukan sampai usia pensiun, yaitu 70 tahun. ${ }^{60}$ Di Jerman ditentukan hakim dan hakim agung diangkat untuk masa jabatan seumur hidup, tetapi undangundang juga dapat menetapkan masa batas pensiun bagi hakim yang diangkat seumur hidup tersebut. ${ }^{61}$

\section{Penutup}

Perundang-undangan yang pernah ada mulai indische staatsregeling (UUD Hindia Belanda), UU No. 15 Tahun 1961, UU No. 5 Tahun 1991 hingga UU No.16 Tahun 2004 tidak ada yang mengatur secara definitif maupun limitatif berapa lama seorang Jaksa Agung menduduki jabatannya. Namun setelah pemilu 1971 Presiden Soeharto memulai sebuah konvensi ketatanegaraan, yakni Jaksa Agung yang selalu diangkat di awal kabinet dan

55 Jimly Asshiddiqie dan Ahmad Syahrizal, "Peradilan Konstitusi di Sepuluh Negara", (Jakarta: Setjen dan Kepanietraan MKRI, 2008), hal. 47.

${ }^{56}$ Lihat Title 7 The Conceil Constitutionnel, Article 56, The Constitution of 1958, (Lihat Pasal 56 Konstitusi Republik Kelima Perancis 1958).

${ }^{57}$ Lihat Pasal 176 Konstitusi Afrika Selatan.

${ }^{58}$ Lihat Pasal 111 ayat (1), (2) dan (3) Konstitusi Korea Selatan.

59 Hon Ha Kyung-chull, "The Constitutional Court System of Korea, The Short History of 15 year-old Challenge", In Firts Regional Seminar of Asian Constitutional Court Judges: Present Status and Future Development of Constitutional Jurisdiction in Asia, Hotel Intercontinental Midplaza, Jakarta September 8, 2003, Jakarta: Mahkamah Konstitusi RI and Konrad Adenauer Stiftung.

${ }^{60}$ Putusan MK No. 49/PUU-VIII/2010, 128.

${ }^{61}$ Lihat Pasal 97 Konstitusi Republik Federal Jerman. 
berakhir masa jabatannya dengan berakhirnya masa bakti kabinet itu. Dengan kata lain masa jabatan Jaksa Agung adalah 5 (lima) tahun.

MK dalam Amar Putusan MK No. 49/PUU-VIII/2010 tentang Pengujian Pasal 22 Ayat (1) Huruf d UU No. 16 Tahun 2004 tentang Kejaksaan RI meskipun dengan amar putusan konstitusional bersyarat (conditionally constitutional) jelas MK lebih mengacu pada fakta konvensi ketetanegaraan ini. Artinya masa jabatan Jaksa Agung sebagai Pejabat Negara setingkat Menteri negara yang menjadi anggota kabinet sebagai pembantu Presiden adalah tetap 5 (lima) tahun, terlepas nanti jika RUU kejaksaan yang baru yang sedang digodok oleh Pembentuk UU, DPR bersama Presiden, saat ini menentukan lain. Karena memang penetapan masa jabatan pejabat publik yang tertuang dalam undang-undang adalah sepenuhnya menjadi kebijakan legislasi yang dijalankan oleh DPR bersama Presiden.

Dalam praktek ketatanegaraan Negara Republik Indonesia terdapat aturan-aturan yang tegas mengenai sistem penetapan masa jabatan pejabat publik, seperti Presiden ditetapkan masa jabatannya selama 5 (lima) tahun dan hanya dapat dipilih kembali untuk satu periode setelahnya, masa jabatan anggota Komisi Yudisial selama masa 5 (lima) tahun dan sesudahnya dapat dipilih kembali untuk 1 (satu) kali masa jabatan, masa jabatan Hakim Konstitusi selama 5 (lima) tahun dan dapat dipilih kembali hanya untuk 1 (satu) kali masa jabatan berikutnya atau masa jabatan tersebut berakhir karena memasuki usia pensiun 67 tahun dan masa jabatan Hakim Agung ditentukan sampai usia pensiun 70 tahun.

Berdasaran kenyataan demikian, dalam rangka memberikan kepastian hukum maka seharusnya penetapan masa jabatan pejabat publik seperti juga penetapan masa jabatan Jaksa Agung selayaknya ditentukan secara definitif dan limitatif sebagaimana penetapan masa jabatan pejabat publik lainnya seperti Presiden, Komisi Yudisial, Hakim Konstitusi, dan Hakim Agung. 


\section{Daftar Pustaka}

\section{Buku/Makalah/Jurnal}

Asshiddiqie, Jimly. Hukum Acara Pengujian Undang-Undang, Jakarta: Konpress, 2006.

Asshiddiqie, Jimly. Perkembangan dan Konsolidasi Lembaga Negara Pasca Reformasi, Jakarta: Sekretariat Jenderal dan Kepaniteraan MKRI, 2006.

Asshiddiqie, Jimly. dan Syahrizal, Ahmad. Peradilan Konstitusi di Sepuluh Negara, Jakarta: Setjen dan Kepanietraan MKRI, 2009.

Atmosudirdjo, S. Prajudi. Hukum Administrasi Negara, Jakarta: Ghalia Indonesia, 1994.

Badan Administrasi Kepegawaian Negara, "Kebijakan Kepegawaian Negara dalam Rangka Penyelenggaraan Pemerintahan Pasca Pemilu 1999”, Bahan Presentasi pada Rakernas Depdikbud, 17 Mei 1999 di Jakarta, 17 Mei 1999.

Effendy, Marwan. Kejaksaan RI Posisi dan Fungsinya dari Perspektif Hukum, Jakarta: Gramedia, 2005.

Fakultas Hukum Universitas Andalas. Perkembangan Pengujian Perundang-Undangan di Mahkamah Konstitusi dari Berpikir Hukum Tekstual Ke Hukum Progresif, Hasil Penelitian Pusat Studi Konstitusi (PUSaKO) Fakultas Hukum Universitas Andalas, 2010.

Hadjon, Philipus M., dkk. Pengantar Hukum Administrasi Indonesia, Yogyakarta: Gadjah Mada University Press, 1993.

Kyung-chull, Hon Ha. "The Constitutional Court System of Korea, The Short History of 15 year-old Challenge", In Firts Regional Seminar of Asian Constitutional Court Judges: Present Status and Future Development of Constitutional Jurisdiction in Asia, Hotel Intercontinental Midplaza, Jakarta September 8, 2003, Jakarta: Mahkamah Konstitusi RI and Konrad Adenauer Stiftung, 2003.

Mahkamah Konstitusi RI. Mengawal Demokrasi Menegakkan Keadilan Substantif; Refleksi Kinerja MK 2009 Proyeksi 2010. Jakarta, 29 Desember 2009.

Nazriyah, Riri. 2010. "Pemberhentian Jaksa Agung dan Hak Prerogatif Presiden", Jurnal Konstitusi, Vol. 7 No. 2 Oktober 2010. Jakarta: Sekretariat Jenderal dan Kepaniteraan Mahkamah Konstitusi

Partanto, Pius A. dan M. Dahlan Al Barry. Kamus Ilmiah Populer. Surabaya: Arkola, 2001. 
Rachman, H.M.A. 2004. "Kemandirian Kejaksaan RI dalam Melaksanakan Fungsi Penegakkan Hukum", Makalah yang Disampaikan pada Ceramah Jaksa Agung RI pada Acara Seminar Sehari dalam Rangka Peringatan 50 Tahun Pendidikan Hukum Universitas Airlangga, Sabtu 9 Oktober 2004

Tim Penyusun Buku Enam Tahun MK. Enam Tahun Mengawal Konstitusi dan Demokrasi; Gambaran Singkat Pelaksanaan Tugas Mahkamah Konstitusi 2003-2009, Jakarta: Sekretariat Jenderal dan Kepaniteraan MK, 2008.

Voermans, Wim. Raden voor de Rechtpraak in landen van de Europese Unie, Terj. Adi Nugroho dan M. Zaki Hussein, 2002, Jakarta: LeIP, 2002.

Westra, Patriata (eds.). Ensiklopesi Administrasi, Jakarta: CV. Haji Masagung, 1989.

\section{Website}

<http://www.jimly.com/tanyajawab?>, diakses tanggal 1 Juli 2011.

$<$ http://www.jimly.com/tanyajawab?page=977>, diakses tanggal 1 Juli 2011.

$<$ http://yancearizona.wordpress.com/2008/11/12/>, diakses tanggal 1 Juli 2011.

$<$ http://yancearizona.wordpress.com/2008/11/12/dibalikkonstitusionalitas-bersyarat-putusan-mahkamah-konstitusi/>, diakses tanggal 1 Juli 2011.

$<$ http://yusril.ihzamahendra.com/2010/08/08/>, diakses tanggal 1 Juli 2011.

$<$ http://yusril.ihzamahendra.com/2010/08/27/permohonan-uji-materil-uuKejaksaan-ke-mk/>, diakses tanggal 1 Juli 2011.

\section{Aturan Hukum}

Undang-Undang Dasar Negera Republik Indonesia 1945 (UUDNRI 1945)

UUD Amerika Serikat.

The Frances Constitution of 1958.

Konstitusi Republik Kelima Perancis 1958.

Konstitusi Afrika Selatan.

Konstitusi Korea Selatan.

Konstitusi Republik Federal Jerman. 


\section{Undang-Undang}

Undang-Undang Nomor 15 Tahun 1961 tentang Ketentuan-Ketentuan Pokok Kejaksaan (LN 1961 No. 254).

Undang-Undang Nomor 14 Tahun 1985 tentang Mahkamah Agung.

Undang-Undang Nomor 5 Tahun 1986 tentang Peradilan Tata Usaha Negara.

Undang-Undang Nomor 5 Tahun 1991 tentang Kejaksaan Republik Indonesia (LN 1991/59; TLN No. 3451).

Undang-Undang Nomor 28 Tahun 1999 tentang Penyelenggaraan Negara Yang Bersih dan Bebas dari Korupsi, Kolusi dan Nepotisme.

Undang-Undang Nomor 43 tahun 1999 tentang Perubahan Atas UndangUndang Nomor 8 tahun 1974 tentang Pokok-Pokok Kepegawaian.

Undang-Undang Nomor 24 Tahun 2003 tentang Mahkamah Konstitusi (LN 2003 No. 98, TLN No. 4316).

Undang-Undang Nomor 9 Tahun 2004 tentang Perubahan Atas UndangUndang Nomor 5 Tahun 1986 tentang Peradilan Tata Usaha Negara.

Undang-Undang Nomor 16 Tahun 2004 tentang Kejaksaan Republik Indonesia.

Undang-Undang Nomor 22 Tahun 2004 tentang Komisi Yudusial (LN 2004 No. 89, TLN No. 4415).

Undang-Undang Nomor 14 Tahun 2008 tentang Keterbukaan Informasi Publik.

Undang-Undang Nomor 3 Tahun 2009 tentang Perubahan Ke Dua Atas Undang-Undang Nomor 14 Tahun 1985 tentang Mahkamah Agung (LN 2009 No. 3, TLN. 4958).

\section{Putusan}

Putusan Mahkamah Konstitusi Nomor 49/PUU-VIII/2010 Tentang Pengujian Undang-Undang Nomor 16 Tahun 2004 Tentang Kejaksaan RI. 